\title{
ARTICLE
}

\section{From Bushfires to Misfires: Climate-related Financial Risk after McVeigh $v$. Retail Employees Superannuation Trust}

\author{
Esmeralda Colombo"
}

First published online 1 September 2021

\begin{abstract}
The year 2020 proved to be a clarion call for global society. There is no longer doubt that increasingly we are experiencing unpredictable events, known as 'black swans', ranging from pandemics to financial meltdowns. One of the 'climate black swans' against which experts have cautioned is the financial crisis caused by climate change. In this context, the Australian case of McVeigh v. Retail Employees Superannuation Trust for the first time tested climate risk and the fiduciary duties of retail pension funds. Settled in November 2020, the case has already raised the bar for climate risk practice in pension funds. In particular, $M c$ Veigh suggests that courts, as well as out-of-court settlements, may articulate a duty, rather than grant permission, for pension funds to consider climate-related financial risk in their investment decisions.

The article builds on McVeigh to ask two questions. Firstly, what is the role of climate change litigation in promoting climate regulation by pension funds? Secondly, what is the relative importance of pension funds for the risk management of climate-related financial risk via due diligence compared with risk assessment via disclosure? Fundamentally, the article explains climate-related financial risk as a cultural phenomenon and argues that a discussion on pension fund fiduciary duties must consider disclosure in addition to due diligence. It argues that McVeigh articulated the need for a normative approach to pension fund disclosure duties and an extension of the field of climate-related risk disclosure to embrace climate-related risk due diligence.
\end{abstract}

Keywords: Climate change litigation, Climate risk, Pension funds, Fiduciary duties, Disclosure, Due diligence

* Climate and Energy Transformation, University of Bergen (Norway); Legal Fellow, Centre for International Sustainable Development Law, Montreal (Canada).

Email: esmeralda.colombo@uib.no.

The author would like to express her deepest gratitude to the peer reviewers of TEL for their helpful comments on the article. Gratitude is expressed also to the participants of the third annual conference with the Global Research Alliance for Sustainable Finance and Investment for invaluable discussions on a previous version of this article (Columbia University, New York, NY (United States (US)), 8-11 Sept. 2020, online event). This publication resulted in part from research funded by the Professor Arvid Frihagens offentligrettslige minnefond, Saks nr 2019/52/FOL, which I gratefully acknowledge. 


\section{INTRODUCTION}

This article centres on two questions. Firstly, what is the role of climate change litigation in promoting climate regulation by pension funds? Secondly, what is the relative importance of risk management of climate-related financial risk (via due diligence) compared with risk assessment (via disclosure) in pension funds? McVeigh v. Retail Employees Superannuation Trust,${ }^{1}$ a recently settled Australian case on climate-related financial risk, is the first to address these two questions, and elucidates a possible approach to how pension funds should account for climate-related financial risk. In particular, this article argues that McVeigh articulates the need for a normative approach to pension fund disclosure duties. It also extends the field of climate-related risk disclosure to embrace climate-related risk due diligence.

The year 2020 will be imprinted on the minds of present and future generations as a result of the worldwide COVID-19 pandemic. Some initially saw COVID-19 as a black swan: an unexpected, wide-ranging or extreme event that can be explained only after it has occurred. ${ }^{2}$ More recently, COVID-19 has proved to be a foreseeable consequence of climate change and biodiversity disturbance. ${ }^{3}$ However, pandemics are neither the sole candidates for inclusion in history books nor the only objects of black swan-informed debates. ${ }^{4}$ Climate change has long generated black swans, called 'climate black swans' or 'green swans', which can simultaneously materialize as extreme financial disruptions. ${ }^{5}$ Notably, black swan-informed debates, be they about pandemics or climate change, may enable a more resilient political infrastructure to combat risks and uncertainties.

Along these lines, a landmark climate change lawsuit concerning green swans swept its way up to Australia's Federal Court. Initially filed in 2018, McVeigh v. Retail Employees Superannuation Trust tested, for the first time, the climate-related financial risk and fiduciary duties of retail superfunds, which are pension funds that accept members from all occupations and industries. ${ }^{6} \mathrm{McVeigh}$ differs substantially from previous unsuccessful lawsuits in which beneficiaries attempted to bring their pension funds to court over failure to disclose and manage climate-related financial risk. These suits were brought vis-à-vis corporate superfunds (pension funds that employers arrange for their employees). Further, such cases occurred mainly in the United States (US), where claims

1 Mark McVeigh v. Retail Employees Superannuation Pty Ltd, Federal Court of Australia, NSD1333/ 2018, Amended Complaint, 21 Sept. 2018.

2 N.N. Taleb, The Black Swan: The Impact of the Highly Improbable, $2^{\text {nd }}$ edn (Random House, 2010), pp. xxi-xxii.

3 See, e.g., G. Wong et al., 'Zoonotic Origins of Human Coronavirus 2019 (HCoV-19 / SARS-CoV-2): Why Is This Work Important?' (2020) 41(3) Zoological Research, pp. 213-19, at 216.

4 B. Avishai, 'The Pandemic Isn't a Black Swan but a Portent of a More Fragile Global System', The New Yorker, 21 Apr. 2020, available at: https://www.newyorker.com/news/daily-comment/thepandemic-isnt-a-black-swan-but-a-portent-of-a-more-fragile-global-system; J. Norman, Y. Bar-Yam \& N.N. Taleb, 'Systemic Risk of Pandemic via Novel Pathogens - Coronavirus: A Note', New England Complex Systems Institute, 26 Jan. 2020, available at: https:/necsi.edu/systemic-risk-of-pandemic-vianovel-pathogens-coronavirus-a-note.

5 Taleb, n. 2 above, p. 315; P. Bolton et al., The Green Swan: Central Banking and Financial Stability in the Age of Climate Change (Bank for International Settlements, 2020), p. 3.

6 McVeigh, n. 1 above. 
were often based on alleged conflicts of interest and had to meet high pleading standards. ${ }^{7}$ Because of these factors, climate change litigation against pension funds had not led to a reconsideration of pension fund duties in relation to climate change. ${ }^{8}$

$M c V e i g h$ has served as a clear test case because it articulated claims beyond the request of pension fund disclosures, which are reporting duties devoid of a standard of conduct. ${ }^{9}$ A suite of requested remedies included due diligence: a set of processes that business and financial entities undertake concerning policies, risk management, and outcomes to help in identifying, preventing and mitigating adverse impacts. Due diligence is generally more demanding than simple disclosure of information and can imply a standard of conduct, ${ }^{10}$ raising the bar for pension fund compliance.

In a recent turn of events, after denying any wrongdoing, the Retail Employees Superannuation Trust (REST) settled the case for AD (Australian dollars) 57 billion on 2 November 2020. As part of the settlement, REST agreed to comply with both disclosure and due diligence climate-related duties in accordance with the recommendations of the Task Force on Climate-related Financial Disclosures (TCFD). Because McVeigh was settled out of court, REST's commitments are not legally binding. ${ }^{11}$ Nevertheless, they raise the bar for pension fund climate-risk practices and impel questions on how climate-related financial risk can be tackled, for instance, in future court cases or via legislation.

Ultimately, $M c$ Veigh reveals a certain dissatisfaction among beneficiaries about the climate-related risk management policies of their pension funds beyond the limited issue of conflict of interest, which characterized earlier litigation. As institutional investors, pension funds are now faced with more general questions about securing beneficiaries' informed consent on planned investments. Moreover, they are asked to determine whether and how their investment managers make informed decisions regarding climate-related financial risk (see Section 3 below).

The emergence of McVeigh is far from coincidental. It was the culmination of increasing levels of litigation on climate-related financial risk, ${ }^{12}$ including two landmark Australian cases. In 2017 the public interest organization Environmental

7 See also Fentress v. Exxon Mobil Corp, 4:16-cv-03484 (S.D. Tex. 4 Feb. 2019); Lynn v. Peabody Energy Corp, 250 F.Supp.3d 372 (E.D.Mo. 2017); and Roe v. Arch Coal Inc., 4:15-cv-00910 (E.D. Mo. 15 Jan. 2016). Cf. Jander v. Retirement Plans Comm. of IBM, 910 F.3d 620 (2d Cir. 2018). See also J. Faucher \& D. Rudolph, 'Second Circuit Breathes New Life into Company Stock Litigation' (2019) 26(3) Journal of Pension Benefits, pp. 22-5, at 22-3.

8 See Faucher \& Rudolph, ibid., pp. 22-3.

9 See examples in J. Bonnitcha \& R. McCorquodale, "The Concept of "Due Diligence" in the UN Guiding Principles on Business and Human Rights' (2017) 28(3) European Journal of International Law, pp. 899-919, at 907-8.

10 Ibid., p. 900. On the evolving character of due diligence see R.H. Weber \& A. Hösli, 'Climate Change Liability: Comparing Risks for Directors in Jurisdictions of the Common and Civil Law' (2020) 10(2) Climate Law, pp. 151-96, at 170.

11 A. Foerster, 'An Australian Man Successfully Sued His Super Fund over Climate Risk: Here's What that Means for Your Nest Egg', The Conversation, 12 Nov. 2020, available at: https://theconversation.com/ an-australian-man-successfully-sued-his-super-fund-over-climate-risk-heres-what-that-means-for-yournest-egg-149918.

12 See J. Solana, 'Climate Litigation in Financial Markets: A Typology' (2020) 9(1) Transnational Environmental Law, pp. 103-35. For an example of one of the first cases on climate-related financial risk see New York Attorney General v. Peabody (which began with an investigation in 2007, and concluded with a settlement: In re Peabody Energy Corp., Assurance 15-242, 8 Nov. 2015). 
Justice Australia filed Abrahams v. Commonwealth Bank of Australia on behalf of two of the bank's shareholders. ${ }^{13}$ The organization maintained that the Commonwealth Bank of Australia had failed to disclose the climate change-related risks of its investments, resulting in allegedly unfair and untrue financial reporting. This case is notable as one of the first examples of shareholders commencing proceedings over climate-related financial risk disclosures against the financial entity in which they have invested. The case was discontinued in 2017, after the bank's recognition, for the first time, of climate risk in its 2017 annual report and its stated commitment to undertake a climate change scenario analysis in 2018.

The second landmark case is O'Donnell v. Commonwealth, which was filed in 2020 by the legal team who also represented McVeigh. O'Donnell v. Commonwealth involved a law student from Melbourne who brought a class action against the Australian government concerning the climate-related financial risk of sovereign bonds. In her capacity as a sovereign bondholder, O’Donnell alleged misleading and deceptive conduct by the Australian government, as well as concrete breaches of the duties of care and due diligence by government officials. The case is notable for inaugurating a new type of Australian climate litigation, where litigants shift from indirect to direct challenges to government conduct. ${ }^{14}$ More generally, the catastrophic bushfires during the summer of 2019-20, known as Black Summer, constituted a powerful catalyst for climate change awareness and litigation in Australia. ${ }^{15}$

Within this rich seam of cases McVeigh offers the space for a thematic discussion of how to decrease the occurrence of green swans and manage climate-related financial risk in pension funds. Pension funds are crucial actors in at least two ways. Firstly, they are key investors in financial markets, owning USD 44.1 trillion worth of assets worldwide in $2018:{ }^{16}$ Their investment choices will thus affect the likelihood of establishing a low-carbon society. Secondly, pension funds perform a public role by protecting the interests of beneficiaries: they are in a position to assess, manage, and report on the risks of climate change to their assets, potentially advancing climate-aware policies in government offices and the enterprises in which they invest. ${ }^{17}$ However, pension funds have rarely fulfilled this role. Among the world's 100 largest pension funds

13 Abrahams v. Commonwealth Bank of Australia, Federal Court of Australia, No. V879/2017, Concise Statement of Claim, 8 Aug. 2017.

14 J. Peel \& R. Markey-Towler, 'Climate Change Risk and Sovereign Bond Investments: The Case of O'Donnell v Commonwealth of Australia' (2020) 14(3) Carbon \& Climate Law Review, pp. 177-86, at 183. On the accountability-based generation of Australian climate cases see J. Peel, H. Osofsky \& A. Foerster, 'Shaping the "Next Generation" of Climate Change Litigation in Australia' (2017) 41(2) Melbourne University Law Review, pp. 793-844. On the indirectness of previous litigation against the Australian government see J. Peel \& H.M. Osofsky, Climate Change Litigation: Regulatory Pathways to Cleaner Energy (Cambridge University Press, 2015), pp. $20 \mathrm{ff}$.

15 L. Schuijers \& M. Young, 'Climate Change Litigation in Australia: Law and Practice in the Sunburnt Country', Melbourne Legal Studies Research Paper Series, No. 900, 2020, pp. 1-26, at 1, available at: https://brill.com/view/book/edcoll/9789004447615/BP000004.xml.

16 Organisation for Economic Co-operation and Development (OECD), Pension Markets in Focus (OECD, 2019), p. 7. Data includes pension insurance contracts and other retirement savings products.

17 On the impact of pension funds on investee behaviour see also J. Evans, M. Orszag \& J. Piggott, 'Introduction', in J. Evans, M. Orszag \& J. Piggott (eds), Pension Fund Governance: A Global Perspective on Financial Regulation (Edward Elgar, 2008), pp. 1-5. 
only $10 \%$ offer climate-aware investment options, and investments in low-carbon solutions amount to less than $1 \%$ of their assets. ${ }^{18}$

Climate-related financial risk merits reflection as it stands out for its large-scale and long-term nature, representing a unique challenge. ${ }^{19}$ In economic decision making, several actors may incorrectly deem the implications of climate change to be long term and, therefore, largely immaterial in the business cycle horizon (three years), the political cycle horizon (four to five years), the horizon for monetary policies (two to three years), or the financial stability horizon (one decade at the most). ${ }^{20}$ Considering that the risk of climate action failure ranks second by likelihood and first by impact over the next ten years, ${ }^{21}$ it seems timely to centre the discussion of climate-related financial risk in pension funds and related litigation.

To date, voluntariness, rather than binding standards, has shaped the mainstream approach to climate risk in pension funds, notably through the work undertaken by the TCFD. ${ }^{22}$ Unfortunately, voluntary engagement with the financial sector seems insufficient to account for and effectively manage climate risk thoroughly. ${ }^{23}$ The voluntary TCFD instruments constitute an important step forward in the governance of climate-related financial risk but should be complemented by legislation or case law. In this context, I argue that $M c V e i g h$ shows how the discourse on climate risk can be expanded to cover not only voluntary but also binding standards. In particular, I suggest that this expansive discourse provides courts of law with opportunities to clarify and standardize climate-related duties for pension funds.

The article partakes in the burgeoning literature on climate change litigation and transnational law by articulating the ramifications of $M c V e i g h$ and situating the case within a broader discussion of the regulation of climate-related financial risk in pension funds. One study recently found that scholars have regularly overlooked climate change litigation against financial entities. ${ }^{24}$ Moreover, few investigations have engaged with the impact of climate change on financial actors, ${ }^{25}$ a gap this article aims to fill.

18 Asset Owners Disclosure Project (AODP), Pensions in a Changing Climate (AODP, 2018), pp. 25 and 44.

19 TCFD, 'Recommendations of the Task Force on Climate-related Financial Disclosures: Final Report', June 2017, p. ii, available at: https://www.fsb-tcfd.org/publications.

20 M. Carney, 'Breaking the Tragedy of the Horizon: Climate Change and Financial Stability', speech by Mark Carney, Governor of the Bank of England and Chairman of the Financial Stability Board, at Lloyd's of London, London (United Kingdom), 29 Sept. 2015, available at: https://www.bis.org/ review/r151009a.pdf.

21 World Economic Forum (WEF), The Global Risk Report 2020,15 $5^{\text {th }}$ edn (WEF, 2020), pp. 7 and 29.

22 On the overall laissez-faire regulatory approach in terms of compliance with fiduciary duties see S.M. Davis, 'The Costs of Fiduciary Failure: And an Agenda for Remedy', in J.P. Hawley et al. (eds), Cambridge Handbook of Institutional Investment and Fiduciary Duty (Cambridge University Press, 2014), pp. 466-76, at 470-5.

23 Weber \& Hösli, n. 10 above, pp. 155, 164 and 166.

24 J. Setzer \& L.C. Vanhala, 'Climate Change Litigation: A Review of Research on Courts and Litigants in Climate Governance' (2019) 10(1) WIREs Climate Change online article e580, pp. 1-19, at 7, available at: https://wires.onlinelibrary.wiley.com/doi/10.1002/wcc.580, who refer to the exception offered by B. Franta, 'Litigation in the Fossil Fuel Divestment Movement' (2017) 39(4) Law \& Policy, pp. 393411, and Solana, n. 12 above.

25 F. Lamperti et al., 'The Public Costs of Climate-induced Financial Instability' (2019) 9 Nature Climate Change, pp. 829-33. 
The article proceeds as follows. Firstly, it examines McVeigh, the first lawsuit filed against a retail public fund with an invocation of TCFD-based standards (Section 3). Sections 4 and 5 survey the TCFD instruments and the myriad opportunities they open for risk management regulation, particularly in the light of the literature on behavioural law and economics and socio-legal studies, including the literature on black swans. The final section offers a brief reflection on the needed regulatory infrastructure for governing climate-related financial risk in pension funds.

\section{APPROACH}

This article builds on McVeigh, a global first in climate change litigation against pension funds, to respond to two research questions. It enquires into (i) the role of climate change litigation in promoting climate regulation by pension funds; and (ii) the relative importance of risk management for climate-related financial risk via due diligence compared with risk assessment via disclosure in pension funds.

The core assumption in this research is that climate change is legally disruptive. Climate change needs adaptive legal regimes, which historically tend towards stability. ${ }^{26}$ In the absence of authoritative statements by international courts and tribunals, ${ }^{27}$ scholars and national courts identify and interpret relevant norms, ${ }^{28}$ thus adapting existing mechanisms to the challenges posed by climate change. ${ }^{29}$ The resistance of law to change can be tackled by identifying and interpreting normative standards and drawing on studies in the social sciences to fully comprehend how such standards can affect society. I will sketch the approach to norms and the use of social sciencebased frameworks in the following.

In terms of normative standards, this article draws minimally on domestic (Australian) law. ${ }^{30}$ Because the article focuses on the ramifications of McVeigh in Australia and beyond, it centres on the innovative transnational regulatory instruments referred to in McVeigh and agreed to by REST in its settlement with the

26 E. Fisher, E. Scotford \& E. Barritt, 'The Legally Disruptive Nature of Climate Change' (2017) 80(2) The Modern Law Review, pp. 173-201, pp. 178-83 (listing the need for adaptive regimes among the four disruptions posed by climate change to law). See confirmation of legal system stability in the 'endowment effect', as described by R. Korobkin, 'Wrestling with the Endowment Effect, or How to Do Law and Economics without the Coase Theorem', in E. Zamir \& D. Teichman (eds), The Oxford Handbook of Behavioral Economics and the Law (Oxford University Press, 2014), pp. 300-34, at 318-29.

I do not refer to regional courts and tribunals. See hypotheticals of climate change litigation before international courts and tribunals in, e.g., P. Sands, 'Climate Change and the Rule of Law: Adjudicating the Future in International Law' (2016) 28(1) Journal of Environmental Law, pp. 19-35, at 19.

28 See also B. Mayer, The International Law on Climate Change (Cambridge University Press, 2018), p. 250.

29 On adaptation through judicial decisions to address the challenge of climate change see B.J. Preston, 'Climate Change Litigation (Part 1)' (2011) 5(1) Carbon \& Climate Law Review, pp. 3-14, at 14.

30 Documents pertaining to climate change litigation were retrieved from a database search in the Sabin Center Databases on Climate Change Litigation, available at: https://perma.cc/8UWT-PYXK. Documents were complemented with scholarly work, non-governmental organization (NGO) documents, newspaper archives, reports, information from lawyers belonging to the jurisdiction under analysis or involved in the case, and web browser searches. I carried out qualitative analyses of the collected data. 
plaintiff. ${ }^{31}$ The TCFD provides these innovative transnational regulatory instruments, which I qualify as soft law: a set of global instruments devoid of domestic or international binding effect. ${ }^{32}$ As soft law, the TCFD instruments are not grounded in any specific legal system or culture: they thus appear to belong to transnational law, meaning 'all law which regulates actions or events that transcend national frontiers', 33 particularly norms that are produced in a transnational setting. ${ }^{34}$

Transnational law is intended to move our intellectual horizon beyond the state towards an enhanced understanding of multiple systems of law, as well as of public and private governance in action. ${ }^{35}$ Importantly, transnational law 'breaks' traditional 'frames', ${ }^{36}$ for instance, when it requires domestic courts to take a stance vis-à-vis normative instruments that have not originated in state-centred legal systems but are rather examples of law external to one state, such as the TCFD instruments or lex mercatoria. $^{37}$

Existing approaches to climate-related financial risk are epitomized by the TCFD instruments, which McVeigh's complaint and settlement consolidated as the relevant standard for the management of climate risk in pension funds. Although it articulates standards for reporting climate-related financial risk, the TCFD stops short of offering a general definition of risk. Financial law provides several interpretations, and the concept of risk is itself dynamic. ${ }^{38}$ Nevertheless, it seems appropriate to apply one of the most influential definitions of risk: measurable uncertainties, as opposed to those that are unmeasurable. ${ }^{39}$ The context of climate change, where many uncertainties are unmeasurable, thus allows for identifying in the term 'risk', as used by the TCFD, both risks and uncertainties.

31 On the general relevance, and the subcategory, of climate litigation in financial markets upon disclosure obligations and the breach of fiduciary duties see Solana, n. 12 above, pp. 117-23 and 125-31.

32 Referring to international soft law instruments, see M. Kanetake \& A. Nollkaemper, 'The Application of Informal International Instruments before Domestic Courts' (2014) 46(4) The George Washington International Law Review, pp. 765-807, at 771. On soft law as 'a set of written, advisory prescriptions' see A.L. Newman \& E. Posner, Voluntary Disruptions: International Soft Law, Finance, and Power (Oxford University Press, 2018), p. 32. A thorough definition of soft law still eludes scholarship: ibid., pp. 2 and 15.

33 P.C. Jessup, Transnational Law (Yale University Press, 1956), p. 2.

34 For this specification of Jessup's general definition see V. Heyvaert, Transnational Environmental Regulation and Governance (Cambridge University Press, 2019), p. 30.

35 See, e.g., V. Heyvaert \& T.F.M. Etty, 'Introducing Transnational Environmental Law' (2012) 1(1) Transnational Environmental Law, pp. 1-11, pp. 4-5.

36 G. Teubner, 'Breaking Frames: Economic Globalization and the Emergence of Lex Mercatoria' (2002) 5(2) European Journal of Social Theory, pp. 199-217; E. Fisher, 'The Rise of Transnational Environmental Law and the Expertise of Environmental Lawyers' (2012) 1(1) Transnational Environmental Law, pp. 43-52, at 49.

37 Teubner, ibid.

38 L. Amorello, 'A Theory of the Origin of Financial Regulation: How Legal Layers Shape International Financial Systems', in F. Fiorentini \& M. Infantino (eds), Mentoring Comparative Layers: Methods, Times, and Places: Liber Discipulorum Mauro Bussani (Springer, 2020), pp. 151-73, at 156; see, in particular, n. 3.

39 F.H. Knight, Risk, Uncertainty and Profit (Kelley, 1964 (original 1921)), pp. 233-34; see also A. Arcuri, 'Reconstructing Precaution, Deconstructing Misconceptions' (2007) 21(3) Ethics \& International Affairs, pp. 359-79. 
However, it should be recognized that the TCFD instruments do not exhaust the understanding of climate risk as a financial risk, which originated well before the TCFD. ${ }^{40}$ Moreover, significant regulation by other institutions - often inspired by the TCFD initiative - has emerged, if sparsely and unevenly. ${ }^{41}$ In Australia, for instance, the Australian Prudential Regulation Authority (APRA) and the Reserve Bank have endorsed the TCFD instruments through non-binding declarations. ${ }^{42}$ Similarly, after the $M c V e i g h$ case was filed, climate change was identified as a financial risk that directors of listed entities may consider disclosing in line with the TCFD. ${ }^{43}$

Concerning the toolkit provided by the social sciences, this article infuses legal scholarship with findings from behavioural law and economics, the sociology of law, and criminal sociology. ${ }^{44}$ While behavioural law and economics approaches reveal certain false assumptions regarding the regulation of transnational economic actors, the sociology of law and criminal sociology shed light on the role of culture, notably organizational culture and the misfires it can generate, to illustrate a possible path forward. ${ }^{45}$

\section{MCVEIGH V. RETAIL EMPLOYEES SUPERANNUATION TRUST}

This section presents and articulates the ramifications of $M c V e i g h$ in the wider discussion of regulating climate-related financial risk in pension funds. It provides a preliminary assessment of the role of climate change litigation in promoting climate regulation by pension funds.

In 2018, then 23-year-old ecological landscaper Mark McVeigh sued Retail Employees Superannuation Trust (REST), to which he had contributed since 2013. As a fund to provide for McVeigh's retirement, REST would enable him to access his savings only in 2055. Before the Federal Court of Australia, McVeigh alleged that

40 See, e.g., T.R. Carter et al., 'Climate Scenario Development', in IPCC 2001 (J.T. Houghton et al. (eds)), Climate Change 2001: The Scientific Basis. Contribution of Working Group I to the Third Assessment Report of the Intergovernmental Panel on Climate Change (Cambridge University Press, 2001), pp. 73968 , at $756 \mathrm{ff}$ (on risk analysis, but short of a discrete consideration of financial risk); United Nations Environment Programme Finance Initiative (UNEP FI), 'CEO Briefing: A Document of the UNEP FI Climate Change Working Group', Aug. 2002 (on climate risk to the global economy); Carbon Disclosure Project (CDP), 'Investor Research Project: Investor Use of CDP Data', 2009; and M. Bowman, Banking on Climate Change: How Finance Actors and Transnational Regulatory Regimes are Responding (Wolters Kluwer, 2015) (the first monograph of its kind on corporate climate finance and transnational regulatory regimes).

41 UNEP FI \& Principles for Responsible Investment (PRI), 'Fiduciary Duty in the 21st Century: Final Report', Oct. 2019, p. 14 (generally on instruments that promote pension fund sustainable investment).

42 G. Debelle, 'Climate Change and the Economy', speech, Centre for Policy Development, Sydney, NSW (Australia), 12 Mar. 2019, available at: https://www.bis.org/review/r190313d.pdf.

43 Australian Securities \& Investments Commission, Regulatory Guide 247, Aug. 2019, para. RG 247.66, available at: https://download.asic.gov.au/media/5230063/rg247-published-12-august-2019.pdf.

44 See Sections 3 and 4 below.

45 E. Fisher et al., 'Maturity and Methodology: Starting a Debate about Environmental Law Scholarship' (2009) 21(2) Journal of Environmental Law, pp. 213-50, at 222, 224, 233, 235, 247, 241-2 (on the role of socio-legal scholarship to reflect critically on law and the need to deepen the interrelationship between local, national, regional and international environmental norms). On the role of behavioural economics for climate policy design, in particular, policy design targeting the financial sector, see M. Bowman, 'Nudging Effective Climate Policy Design' (2011) 35(2) International Journal of Global Energy Issues, pp. 242-54. 
REST violated Australia's 2001 Corporations Act by failing to provide requested information on the fund's assessment and management of climate-related financial risk, ${ }^{46}$ thus impairing McVeigh's informed decision making about the fund management and its financial condition. In an amended complaint McVeigh added that REST breached its duties as a trustee and violated Australia's Superannuation Industry (Supervision) Act of 1993 (SIS Act) by failing to demand that its investment managers present information on climate-related financial risk for the REST board of Directors to consider. ${ }^{47}$ Moreover, McVeigh deemed REST non-compliant with the SIS Act by failing to ensure that the fund's disclosure and management of climate-related financial risk complied with the TCFD Recommendations, a voluntary initiative that catalyzed the study and practice of climate-related financial risk. ${ }^{48}$

In January 2019, upon McVeigh's application, Justice Nye Perram considered the issuing of a 'maximum costs order'. In most matters adjudicated by the Australian Federal Court, the unsuccessful party bears part of the legal costs of the successful party, but maximum costs orders limit the liability of the unsuccessful party at the end of judicial proceedings. As such, maximum costs orders allow plaintiffs to bring matters in the public interest. ${ }^{49}$ In examining the application for this order, Judge Perram remarked that the case was not 'a dry Chancery suit'. ${ }^{50}$ Rather, it seemed to 'raise a socially significant issue about the role of superannuation trusts and trustees in the current public controversy about climate change'. ${ }^{51}$ The judge further commented that the 'basic structure of the Applicant's case' was 'relatively straightforward and not hopeless'. Conclusively, the case was considered litigation in the public interest. ${ }^{52}$ However, absent relevant information on McVeigh's assets and willingness to pursue the proceedings short of a costs cap, the judge refrained from issuing the maximum costs order and reserved the matter for subsequent phases of the proceedings. ${ }^{53}$

Unfortunately, REST's arguments at the trial have not been disclosed and can only be gleaned through the words of Justice Perram. Firstly, REST disputed the public interest character of the litigation. ${ }^{54}$ Secondly, it replied to McVeigh's requests for more information by pointing to publicly available information on its website and highlighting its assurance that climate change is a relevant consideration, stopping short of providing the plaintiff with further details. ${ }^{55}$ Overall, the court order in McVeigh underscored that the case concerned the duties of superannuation trustees in relation

46 Corporations Act, 2001, s. 1017C; and Superannuation Industry (Supervision) Act, 1993 (SIS Act), s. $52(2)(\mathrm{j})$.

47 SIS Act, s 52(2)(b) and (c), s 52(6)(a).

48 McVeigh, n. 1 above.

49 Federal Court Rules, r. 40.51; Australian Capital Territory Supreme Court in Kent v. Cavanagh (1973) 1 ACTR 43, p. 55; Arnold v. Queensland (1987) 73 ALR 607, pp. 621-2 and 635; and Woodlands v. Permanent Trustee Company Ltd [1995] FCA 1388; (1995) 58 FCR 139, paras $23 \mathrm{ff}$.

51 Ibid.

52 On both points see ibid., para. 13.

53 Ibid., paras 12-20.

54 Ibid., para. 3.

55 Ibid., para. 5. 
to climate change, and clarified that it could prompt REST to divulge more material about how it fulfilled its duties. ${ }^{56}$

On 2 November 2020 - shortly before the start of the trial - the case was settled, with REST agreeing to comply with McVeigh's requests through a set of commitments, which can be summarized as follows. Firstly, REST committed to aligning its portfolio with the Paris Agreement ${ }^{57}$ and measuring, monitoring and reporting outcomes on its Paris Agreement-related climate objectives and climate actions in line with the TCFD Recommendations. Secondly, consistent with the Paris Agreement, REST consented to achieve net-zero emissions by 2050 and undertake scenario analyses compatible with the global carbon budget of $2{ }^{\circ} \mathrm{C}$ (degrees Celsius) by disclosing climate risk and conducting due diligence over its investees and investment managers. ${ }^{58}$ Thirdly, REST accepted the responsibility to encourage its investee companies to make disclosures in line with the TCFD Recommendations, inducing a spillover effect of investee compliance with the TCFD Recommendations. ${ }^{59}$ Fourthly, contrary to current practice, REST undertook the full disclosure of its entire portfolio, thus providing its beneficiaries and the public with data that might expose future inconsistencies with the Paris Agreement or the TCFD Recommendations. ${ }^{60}$

A closer look at $\mathrm{McVeigh}$ reveals four takeaways, allowing for a preliminary assessment of the role of climate change litigation in promoting climate regulation by pension funds. Firstly, that REST agreed to settle the case before trial is suggestive of the salience of climate-related financial risk for pension funds, which had been disputed. ${ }^{61}$ Secondly, although it is non-binding, experts have deemed the settlement reached in $M c V e i g h$ as influential for other retail funds and the entire Australian superannuation industry, which is one of the largest worldwide. ${ }^{62}$ Such a development is of significant consequence. During the 2000s Australia's retail funds rose exponentially in contrast to a relative decrease in public and corporate sector funds. This occurrence can be attributed to changes in legislation that favour the management of pension funds at economies of scale, greater employee turnover and shifts among work sectors. In fact, because lifetime employment had grown less common, Australia's superannuation choice legislation in 2005 required employers to allow employees to shop for pension products from several funds on the market, including the retail sector. ${ }^{63}$ As Australian

56 Ibid., paras 8 and 11.

57 Paris (France), 12 Dec. 2015, in force 4 Nov. 2016 available at: http://unfccc.int/paris_agreement/items/ 9485 php.

58 REST, 'Media Release: Statement from Rest', 2 Nov. 2020, available at: https://equitygenerationlawyers. com/wp/wp-content/uploads/2020/11/Statement-from-Rest-2-November-2020.pdf.

59 Ibid.

60 Foerster, n. 11 above.

61 See also ibid.

62 On the impacts of McVeigh see Foerster, n. 11 above. On Australia's pension fund system, one of the largest worldwide, see G. Noble, 'Institutional Investment and Fiduciary Duty in Australia', in Hawley et al. (eds), n. 22 above, pp. 46-58.

63 Superannuation Legislation Amendment (Choice of Superannuation Funds) Act 2005 (Australia). W. Sy, 'Pension Governance in Australia: An Anatomy and an Interpretation' (2008) 1(1) Rotman International 
retail funds currently top all other fund types in terms of asset value, ${ }^{64}$ the legacy of McVeigh can potentially affect a host of pension funds and beneficiaries.

Thirdly, McVeigh revives the debate on how retail funds address triangular conflicts of interest. In Australia, for instance, retail pension funds are governed by forprofit trustees, who oversee fund managers and advisers operating in open commercial markets. Pursuant to an amendment to the 1993 SIS Act, retail trustee directors will prioritize pension fund member benefits over company shareholder profits, ${ }^{65}$ which may have shorter time frames. In fact, superannuation funds must perform the trustee's duties and exercise the trustee's powers 'in the best interests of the beneficiaries' ${ }^{66}$ The wording clearly shows that the SIS Act was built upon trust law ${ }^{67}$ and does not allow any derogation from this fiduciary duty. ${ }^{68}$ However, what constitutes the beneficiaries' best interests has yet to be elucidated in either legislation or case law. ${ }^{69}$ That is to say, should trustees apply the best interests mandate only to investment management procedures? Or should they also scrutinize the substance of investment management decisions - namely, the material choices made by investment managers in administering the fund on behalf of the trust's beneficiaries, ${ }^{70}$ thus opening up to scrutiny decisions on issues such as climate change impacts on investment?

Fourthly, clarifying fiduciary duties in McVeigh can also elucidate pension fund climate-related financial risk and duties in other jurisdictions, where the question is also a hot topic. ${ }^{71}$ In most countries pension arrangements result from unfunded public schemes, publicly mandated contributory schemes and voluntary private retirement

Journal of Pension Management, pp. 30-47, at 32; see also G. Thompson, 'Risk-based Supervision of Pension Funds in Australia', The World Bank, Policy Research Working Paper 4539, Feb. 2008, pp. 4-8.

64 Sy, ibid., p. 34.

65 Superannuation Legislation Amendment (Trustee Obligations and Prudential Standards) Act 2012 (Cth), s. 52(2)(c); Explanatory Memorandum to the Superannuation Legislation Amendment (Trustee Obligations and Prudential Standards) Bill 2012. See P. Hanrahan, 'Legal Framework Governing Aspects of the Australian Superannuation System', Royal Commission into Misconduct in the Banking, Superannuation and Financial Services Industry, Background Paper 25, July 2018, p. 16. On such conflicts before law amendments see Sy, n. 63 above, pp. 35-6.

66 Superannuation Legislation Amendment (Trustee Obligations and Prudential Standards) Act 2012 (Cth), s. $52(2)(\mathrm{c})$ (emphasis added).

67 C. Brown \& D. Ralston, 'The Poor Performance of Compulsory Saving in Australia: Superannuation and Corporate Governance', in D.G. Mayes \& G. Wood (eds), Reforming the Governance of the Financial Sector (Routledge, 2013), pp. 54-79, at 63.

68 M. Moshinsky, 'The Continuing Evolution of the "Best Interests" Duty for Superannuation Trustees from Cowan v Scargill to the Current Regulatory Framework', Superannuation Committee of the Law Council of Australia, 2018 Superannuation Conference 'Order in the House', 9 Mar. 2018, Canberra, ACT (Australia), pp. 5ff, available at: https://www.fedcourt.gov.au/_data/assets/rtf_file/0009/48582/ Moshinsky-J-20180309.rtf.

69 Ibid., pp. 2-3.

70 On whether pension funds should scrutinize the substance of investment management decisions see Moshinsky, n. 68 above, pp. 18-9.

71 See, e.g., Shift Action for Pension Wealth and Planet Health, 'Canada's Pension Funds and Climate Risk: A Baseline for Engagement', June 2019; and J. Øyrehagen Sunde \& E. Colombo, 'Look to Norway: Klimasøksmål i klimaendringane sin tidsperiode’, Energi og Klima, 26 Sept. 2017, available at: https://energiogklima.no/kommentar/look-to-norway. 
savings. ${ }^{72}$ Fiduciary duties are encased in common and civil law traditions, even though the terminology and enforcement mechanisms may differ. ${ }^{73}$ In the context of pension funds, fiduciary duties exist to ensure that individuals or entities entrusted with other people's money act in the interests of their beneficiaries, behaving honestly and impartially (duty of loyalty), as well as prudently and diligently according to the beneficiaries' instructions (duty of care and diligence). ${ }^{74}$ Despite these guidelines, many pension fund trustees construe fiduciary duties as a mandate to pursue maximum returns on investments, often in the short term. This mandate obfuscates considerations unrelated to profit maximization, ${ }^{75}$ such as climate change-related concerns. Nevertheless, is this construction legitimate? McVeigh suggests that courts, as well as out-of-court settlements, may articulate a duty, rather than simply permit pension funds to consider climate-related financial risk. ${ }^{76}$

Notwithstanding the non-binding character of the out-of-court settlement, $M c V e i g h$ corroborates conclusively the claim that climate change litigation does more than resolve singular cases. It spells out facts and norms for a community at large, thus providing a form of 'expository justice'. 77 Moreover, in the broad spectrum of litigation outcomes spanning 'pyrrhic victories and sublime failures', ${ }^{78} \mathrm{McVeigh}$ signifies once more that the favourable outcomes of climate change litigation are not measured simply by court pronouncements. McVeigh confirms that climate risk is fast morphing into corporate risk, opening the door to new categories of litigant ${ }^{79}$ who enjoy a unique position in vindicating their claims compared with the rest of society, thus surmounting known obstacles to climate justice such as standing restrictions. ${ }^{80}$ At the very least, beneficiaries of pension funds, shareholders of bank stocks, and sovereign bondholders have an economic interest in proper risk assessment and risk management. Further, as concrete interest holders, they can compel corporate and governmental change from within. The role of climate change litigation in promoting climate regulation by pension funds thus seems one of 'expository justice' and the adaptability of the law to the challenges posed by climate change.

72 J. Carmichael \& R. Palacios, 'A Framework for Public Pension Fund Management', in A.R. Musalem \& R.J. Palacios (eds), Public Pension Fund Management: Governance, Accountability, and Investment Policies - Proceedings of the Second Public Pension Fund Management Conference, May 2003 (The World Bank, 2004), pp. 1-48, at 2. The Australian Prudential Regulatory Authority (APRA) classifies the Australian pension system (superannuation) into four major types: corporate, public sector, industry, and retail: Sy, n. 63 above, p. 30.

73 UNEP FI \& PRI, n. 41 above, p. 12.

74 Ibid., pp. 10ff. J. Sandberg, ‘(Re-)Interpreting Fiduciary Duty to Justify Socially Responsible Investment for Pension Funds?' (2013) 21(5) Corporate Governance: An International Review, pp. 436-46, p. 437.

75 See also Sandberg, ibid., p. 437.

76 For an evaluation of how courts can hypothetically adjudicate the fiduciary duties of pension fund trustees see S. Barker et al., 'Climate Change and the Fiduciary Duties of Pension Fund Trustees: Lessons from the Australian Law' (2016) 6(3) Journal of Sustainable Finance \& Investment, pp. 211-44.

77 Fisher, Scotford \& Barritt, n. 26 above, p. 198. On the value of litigation going beyond a legal victory see also J. Peel \& H.M. Osofsky, Climate Change Litigation. Regulatory Pathways to Cleaner Energy (Cambridge University Press, 2015), p. 28.

78 G. Ganguly, J. Setzer \& V. Heyvaert, 'If at First You Don't Succeed: Suing Corporations for Climate Change' (2018) 38(4) Oxford Journal of Legal Studies, pp. 841-68, at 865.

79 Ibid., p. 861.

80 Weber \& Hösli, n. 10 above, p. 160. 


\section{DISCLOSURE: THE 'BUSINESS CASE' FOR CLIMATE-RELATED FINANCIAL RISK}

\subsection{The Task Force on Climate-related Financial Disclosures: Pension Funds}

The complaint and settlement in McVeigh drew heavily on the Recommendations of the TCFD in 2017. Recalling the transnational character of the TCFD Recommendations and their designation as international best practice in climate-related financial risk, ${ }^{81}$ this section sketches the premises, emergence, and content of the TCFD instruments. Moreover, it establishes the background for determining the relative importance of the management of climate-related financial risk via due diligence compared with risk assessment via disclosure in pension funds, which addresses the second research question of this article.

Climate change surfaced as a factor in the voluntary practice of socially responsible investment (SRI) in the 1990s. ${ }^{82}$ However, the SRI niche was unable to influence general investment practices. Public regulation - especially at the state level - was either absent or inadequate. ${ }^{83}$ The term 'climate-related financial risk' appears to have emerged in 2015. In a memorable speech delivered to the insurance market Lloyd's of London on 29 September 2015, then Governor of the Bank of England and Chair of the Financial Stability Board (FSB) Mark Carney described the severe - and possibly systemic - risk for economic actors, including pension funds, of ignoring the effects of climate change in their operations. ${ }^{84}$ As it was delivered, the speech made the headlines in major newspapers. ${ }^{85}$ Just over two months after the speech at Lloyd's, on 4 December 2015 Mark Carney nominated an industry-led task force to analyze risk disclosure in climate change matters, the previously mentioned TCFD, in his capacity as chair of the FSB. ${ }^{86}$

The 2017 Recommendations, released after two public consultations, have been favourably received by countries, civil society, and economic organizations, which enabled their application at the national, regional, and global levels. ${ }^{87}$ In this context, the role of the

81 Foerster, n. 11 above.

82 B.J. Richardson, 'Climate Finance and Its Governance: Moving to a Low Carbon Economy through Socially Responsible Financing?’ (2009) 58(3) International Comparative Law Quarterly, pp. 597626 , at 601.

83 On the SRI sector niche see Richardson, ibid., pp. 609 and 612, and on regulatory gaps, p. 626.

84 Carney, n. 20 above.

85 E.g., L. Elliott, 'Carney Warns of Risks from Climate Change "Tragedy of the Horizon”, The Guardian, 29 Sept. 2015, available at: https:/www.theguardian.com/environment/2015/sep/29/carney-warns-ofrisks-from-climate-change-tragedy-of-the-horizon; N. Irwin, 'One of the World's Most Powerful Central Bankers Is Worried about Climate Change', The New York Times, 30 Sept. 2015, available at: https://www.nytimes.com/2015/10/01/upshot/one-of-the-worlds-most-powerful-central-bankers-isworried-about-climate-change.html.

86 FSB, 'Proposal for a Disclosure Task Force on Climate-related Risks', 9 Nov. 2015; FSB, 'FSB to Establish Task Force on Climate-related Financial Disclosures’, 4 Dec. 2015. On the FSB see Newman \& Posner, n. 32 above, pp. 38-9.

87 On applications at the national, regional, and global levels, see NOU 2018: 17 Klimarisiko og norsk økonomi [Official Norwegian Reports NOU 2018: 17 Climate Risk and the Norwegian Economy], a summary of the report in English is available at: https://www.regjeringen.no/en/dokumenter/nou-201817/id2622043; Communication from the European Commission, 'Guidelines on Non-Financial 
Network of Central Banks and Supervisors for Greening the Financial System (NGFS) should be mentioned. Founded in Paris in 2017, the NGFS now features 77 members and 13 observers among central banks and financial supervisors. ${ }^{88}$ Importantly, the NGFS has pledged the collective support of all its members to the 2017 TCFD Recommendations. In particular, it has encouraged all businesses issuing public debt or equity and the financial sector to make disclosures consistent with the TCFD Recommendations, and has urged policymakers and supervisors to foster their broader adoption. ${ }^{89}$

More broadly, it can be argued that the level of influence that the TCFD has gained originates partly in a convergence of events in 2015: Carney's speech and its international resonance; the momentum of the role of finance for sustainable development, exemplified by Agenda $2030 ;^{90}$ and the adoption of the first international climate treaty provisions engaging with the financial sector, represented by the Paris Agreement. ${ }^{91}$ Indeed, Article 2(1)(c) of the Paris Agreement provides for making finance flows consistent with low greenhouse gas (GHG) emissions and climate-resilient development.

It is fair to say that the 2017 TCFD Recommendations make a 'business case' to consider climate change. Rather than centring on ethical or social responsibility considerations, the Recommendations tackle climate change as a financial risk, which they divide into two categories. Firstly, climate-related financial risk affects assets as a physical risk, either acute (event driven) or chronic (longer term). Secondly, climate-related risk can pose financial liabilities as a transition risk, encompassing policy and legal risks (including liability risk), as well as market, technology, and reputational risks. ${ }^{92}$ Ratione personae, the scope of the Recommendations encompasses organizations in the financial sector, including insurance companies, banks, asset managers and asset owners (with pension funds included in the latter). ${ }^{93}$ Moreover, the Recommendations are addressed to non-financial sectors, which are grouped in three areas: energy, materials and buildings; transportation;

Reporting (Methodology for Reporting Non-Financial Information)' [2017] OJ C 215/1; J. Colas et al., 'Extending Our Horizons: Assessing Credit Risk and Opportunity in a Changing Climate - Outputs of a Working Group of 16 Banks Piloting the TCFD Recommendations. Part 1: Transition-related Risks \& Opportunities', UNEP FI, Apr. 2018; and R. Connell et al., 'Navigating a New Climate. Assessing Credit Risk and Opportunity in a Changing Climate: Outputs of a Working Group of 16 Banks Piloting the TCFD Recommendations. Part 2: Physical Risks and Opportunities', UNEP FI, July 2018. The Recommendations were endorsed by 785 supporters, including 671 firms and 114 other organizations, such as industry associations; see TCFD, '2019 Status Report: Task Force on Climate-Related Financial Disclosures', 5 June 2019, p. 110, available at: https://www.fsb.org/wp-content/uploads/ P050619.pdf; UN \& PRI, PRI Climate Snapshot 2020, 17 July 2020, available at: https://www.unpri. org/climate-change/pri-climate-snapshot-2020/6080.article.

88 On the NGFS see: https://www.ngfs.net/en/about-us/membership.

89 On both points see NGFS, 'A Call for Action: Climate Change as a Source of Financial Risk', Apr. 2019, pp. 3-4, available at: https://www.ngfs.net/sites/default/files/medias/documents/ngfs_first_comprehensive_ report_-_17042019_0.pdf.

90 UNGA, 'Transforming Our World: The 2030 Agenda for Sustainable Development', 21 Oct. 2015, UN Doc. A/RES/70/1, SDG 17; but cf. the unsatisfactory role of companies in Agenda 2030, as remarked by A. Aseeva, '(Un)Sustainable Development(s) in International Economic Law: A Quest for Sustainability’ (2018) 10(11) Sustainability 4022, pp. 1-30, at 17.

91 Paris Agreement, n. 57 above, Arts. 2(1)(c), 6(8), 9(3) and 11(1).

92 TCFD Recommendations, n. 19 above, pp. 5-6 and 16. Cf. the identification of three, instead of two, categories of risks in Carney, n. 20 above: physical risks, liability risks, and transition risks.

93 TCFD Recommendations, n. 19 above, pp. iv and 15-6. 
and agriculture, food and forestry products. ${ }^{94}$ Ratione materiae, the Recommendations adopt an approach based on voluntary disclosure concerning climate-related financial risk in four clusters: governance, strategy, risk management, and metrics and targets. ${ }^{95}$

The financial take on climate risk is apparent from the recommendation for all organizations to disclose their climate-related financial risks in their mainstream (that is, public) annual financial filings. ${ }^{96}$ Not only does this increase the accuracy and specificity of disclosures, mainly through the involvement of audit committees and chief financial officers, but it also fosters transparency, helps to develop disclosure techniques and facilitates shareholder engagement. ${ }^{97}$

In reference to pension funds, the Recommendations endow them with substantial guidance on assessing, managing, and disclosing climate-related financial risk. Similar to other organizations within the remit of the Recommendations, pension funds are encouraged to apply scenario analyses. They are to develop strategic plans based on a $2^{\circ} \mathrm{C}$ temperature increase limit - or lower - scenario, which the Recommendations explicitly ground in Article $2(1)(\mathrm{a})$ of the Paris Agreement. ${ }^{98}$ Given this, the Recommendations urge all organizations to disclose their 'scope 3 emissions' according to the widely influential Greenhouse Gas Protocol. Scope 3 emissions are defined as emissions that occur throughout organizations' value chains (both upstream and downstream) but are not commonly disclosed. ${ }^{99}$ However, the bold emphasis on scope 3 emissions is diluted by the qualifier 'if appropriate', all the more since the circumstances and level of appropriateness have not been specified. ${ }^{100}$

As a relevant investment metric for asset owners to disclose, the Recommendations coined the 'weighted average carbon intensity metric', which measures exposure to carbon-intensive companies expressed as carbon dioxide equivalent tonnes per revenue measured in millions of dollars $\left(\mathrm{CO}_{2} \mathrm{e} / \$ \mathrm{~m}\right.$ revenue $) .{ }^{101}$ The formula, however, fails by default to include scope 3 emissions. ${ }^{102}$ This suggests that organizations will fail to disclose scope 3 emissions even when appropriate. Moreover, the weighted average carbon intensity metric applies only where data is available or can reasonably be estimated for each fund or investment strategy. ${ }^{103}$ This neglect of scope 3 emissions, which constitute the bulk of emissions, is unfortunate.

94 Ibid.

95 Ibid., pp. v and $13 \mathrm{ff}$.

96 Ibid., pp. iv, $\mathrm{v}$ and 17.

97 Ibid.

98 Ibid., p. 27. On scenario analysis as an innovative approach see A. Johnston, 'Climate-related Financial Disclosures: What Next for Environmental Sustainability?', University of Oslo Faculty of Law Research Paper No. 2018-02, Feb. 2018, p. 13, available at: https://papers.ssrn.com/sol3/papers.cfm? abstract_id=3122259.

99 TCFD Recommendations, n. 19 above, p. 22. On sparse practice concerning disclosure of scope 3 emissions see OECD \& Climate Disclosure Standards Board (CDSB), 'Climate Change Disclosure in G20 Countries: Stocktaking of Corporate Reporting Schemes’, Nov. 2015, p. 31.

100 TCFD Recommendations, n. 19 above, p. 22.

101 TCFD, 'Implementing the Recommendations of the Task-Force on Climate-Related Financial Disclosures', June 2017 (TCFD Annex), pp. 37ff; see especially p. 43 for the formula.

102 Ibid., p. 43.

103 Ibid., p. 37. 
In sum, the TCFD Recommendations seem to be defining the discourse on climate-related financial risk. ${ }^{104}$ This comes as no surprise. The underpinning of financial regulation is focused on maintaining stability against the risk of disruption, ${ }^{105}$ and - from social, economic, psychological, and legal perspectives - climate change is exceptionally disruptive. ${ }^{106}$ In this context, the TCFD Recommendations serve as the first instrument to specify and propose a broad financial response to the exceptional economic disruptions that climate change signifies across sectoral and national lines. In particular, this section shows that the TCFD Recommendations contain significant guidelines for pension funds to disclose their climate-related financial risk. However, some critiques can be levelled as to whether the approach developing from the TCFD Recommendations sufficiently regulates the systemic risk posed by pension funds to financial and social stability, given the lack of stringency on crucial metrics.

\subsection{Business as Usual Practice, Systemic Risk and Fallout}

The previous section established the background for gauging the role of the TCFD instruments in the regulation of climate risk by pension funds. Although they define the discourse on climate-related financial risk, the TCFD instruments are not immune to criticism. This section discusses critiques of the instruments to determine the relative importance of the management of climate-related financial risk via due diligence compared with risk assessment via disclosure in pension funds.

The TCFD Recommendations were understood to have as their prime objective the encouragement of disclosure and transparency, operating under the assumptions that markets respond rationally to information, and that such information would foster a shift from 'brown' to 'green' assets. ${ }^{107}$ However, McVeigh shows that observance of the TCFD Recommendations may still allow pension funds to withhold relevant information, not only because the Recommendations are voluntary but also because they can be interpreted conservatively (for example, by leaving out scope 3 emissions). Hence, the TCFD Recommendations seem to allow for 'grey zones', and voluntary disclosure is insufficient to regulate systemic risk. Importantly, the disclosure-based approach of the Recommendations may result in reinforcing business-as-usual practices in pension funds. In fact, notwithstanding the popularity and steady endorsement of the TCFD instruments, recent analyses conclude that most pension funds do not disclose their portfolio holdings. ${ }^{108}$

104 See, e.g., WEF, n. 21 above, p. 33 (pointing to the TCFD as the driver of boardroom discussions on financial exposures and transition, and to its Recommendations as the instrument for mainstreaming the assessment of climate-related financial risk globally).

105 Amorello, n. 38 above, p. 155. See also J.E. Stiglitz, 'The Role of the State in Financial Markets' (1993) 7(1) The World Bank Economic Review, pp. 19-52.

106 See, e.g., Fisher, Scotford \& Barritt, n. 26 above, passim. See also R.J. Lazarus, 'Super Wicked Problems and Climate Change: Restraining the Present to Liberate the Future' (2009) 94(5) Cornell Law Review, pp. 1153-233.

107 N. Ameli et al., 'Climate Finance and Disclosure for Institutional Investors: Why Transparency Is Not Enough' (2020) 160 Climatic Change 565-89.

108 AODP, n. 18 above, pp. 25 and 44; R. Alembakis, 'Majority of Super Funds Not Disclosing Portfolio Holdings: Rainmaker', FS Sustainability, 2 Oct. 2020, available at: https://www.fssustainability.com. $\mathrm{au} / \mathrm{majority-of-super-funds-not-disclosing-portfolio-holdings-rainmaker.}$ 
This lack of disclosure in respect of holdings means that pension funds are likely also to omit the disclosure of any climate risk that impinges on their investments. Alternatively, the TCFD instruments may be inherently insufficient because of the voluntary approach contained within them.

Even when pension funds list their portfolio holdings, such disclosures may prove insufficient to fully account for and act on climate risk. In fact, disclosure-based approaches epitomize neoliberal financial governance whereby the solution to financial stability risk is risk disclosure. Whenever entities release information, the assumption is that the markets will unleash a lightning bolt of 'market discipline' as soon as excessive risk taking and indefensible risk management practices emerge. ${ }^{109}$ However, does the market react efficiently, even upon reliable disclosure? Overconfidence in market efficiency to price all publicly available information optimally at all times animates both public institutions and the private sector, notwithstanding critical literature. ${ }^{110}$ In reality, it has grown apparent that the market has not priced information optimally, even when available, and financial entities have remained largely unaccountable in environmental matters, including climate change. ${ }^{111}$

The consequences of the above shortcomings can be dire and reveal systemic concerns. It was found recently that adverse shocks in the fossil fuel sector, along with increased volatility in other climate-relevant sectors, could widely threaten pension fund equity holdings portfolios in the European Union and the US. ${ }^{112}$ Moreover, the European Systemic Risk Board (ESRB) has calculated the range of potential loss of European financial entities at between EUR 350bn and 400bn, even when the transition to a low-carbon society is assumed to occur in an orderly fashion. ${ }^{113}$

In Australia, the Reserve Bank has signalled that superannuation and investment funds are exposed to climate-related financial risk through direct investments in carbon-intensive industries and indirect investments in banks that lend to these industries. ${ }^{114}$ This negative outlook worsens when considering the societal role of pension funds. Such funds provide pensioners with benefits and are critical for the viability of the welfare state, which posits society's responsibility to provide all citizens with a

109 B. Christophers, 'Climate Change and Financial Instability: Risk Disclosure and the Problematics of Neoliberal Governance' (2017) 107(5) Annals of the American Association of Geographers, pp. $1108-27$, at 1109 and $1113 \mathrm{ff}$.

110 On the efficient markets hypothesis see E.F. Fama, 'Efficient Capital Markets: A Review of Theory and Empirical Work' (1970) 25(2) The Journal of Finance, pp. 383-417. On critical theory see, e.g., G.L. Clark, 'Myopia and the Global Financial Crisis: Context-specific Reasoning, Market Structure, and Institutional Governance' (2011) 1(1) Dialogues in Human Geography, pp. 4-25, at 7; and R. Shiller, 'Bubbles, Human Judgment, and Expert Opinion' (2002) 58(3) Financial Analysts Journal, pp. 18-26, at 23.

111 See, e.g., Barker et al., n. 76 above.

112 S. Battiston et al., 'A Climate Stress-Test of the Financial System' (2017) 7 Nature Climate Change, pp. 283-8, at 285 (calculating $45.2 \%$ exposure for insurance and pension funds).

113 ESRB Advisory Scientific Committee, 'Too Late, Too Sudden: Transition to a Low-carbon Economy and Systemic Risk', Reports of the Advisory Scientific Committee, ASC Report No. 6, Feb. 2016, p. 12, available at: https://www.esrb.europa.eu/pub/pdf/asc/Reports_ASC_6_1602.pdf.

114 Reserve Bank of Australia, 'Financial Stability Review, October 2019: Box C Financial Stability Risks from Climate Change', Oct. 2019, available at: https://www.rba.gov.au/publications/fsr/2019/oct/boxc-financial-stability-risks-from-climate-change.html. 
certain level of social goods. ${ }^{115}$ Even in countries that do not define themselves as progressive welfare states, including liberal regimes such as Australia, public regulation of the pension system has intensified, resulting in increased public pension provisions and mandated non-state pensions. ${ }^{116}$

From a regulatory perspective, the cognitive dissonance between the assumption of market efficiency and climate financial risk is concerning and suggests that climate risk disclosures, as propounded by the TCFD, will have a necessarily limited impact. The homo oeconomicus hypothesis has long been disproved; in a context of bounded rationality, market players construct simplified models ${ }^{117}$ and prefer being wrong as part of a group (so-called herding behaviour) to countering the mainstream alone. ${ }^{118}$ Herding stems not only from human psychology but is further reinforced by regulation, which requires pension funds to act as prudent persons in the exercise of fiduciary duties, implying conventional approaches. ${ }^{119}$

Here, climate-related financial risk adds a further complication: it exceeds the modern portfolio theory's approach to risk as normally distributed. In climate change matters risk is not distributed normally. Instead, climate events often manifest as black swans, unexpected events that can be explained only after they occur. ${ }^{120}$ As such, climate risk is distributed with 'fat tails', meaning that past data cannot predict the occurrence of climate-related events, yet the probability of catastrophic outcomes is insufficiently small to provide comfort. ${ }^{121}$ In sum, when regulation leans on existing instruments governing investment risk, it incorporates inaccurate assumptions for climate-related risk distribution.

A further complication attached to climate-related financial risk is widely known as the 'tragedy of the horizons', after Carney's seminal speech. ${ }^{122}$ Investors apply

115 B.M. Baker, 'The Welfare State: Objectives, Subordinate Principles and Justifying Grounds', in A. Peczenik \& M.M. Karlsson (eds), Law, Justice and the State Essays on Justice and Rights (Steiner Verlag, 1995), pp. 170-8, at 170.

116 P. Bridgen, 'The Retrenchment of Public Pension Provision in the Liberal World of Welfare during the Age of Austerity - and Its Unexpected Reversal, 1980-2017’ (2019) 53(1) Social Policy \& Administration, pp. 16-33, at 28. On this classification of Australia see the seminal G. Esping-Andersen, The Three Worlds of Welfare Capitalism (Polity Press, 1990), pp. 48-9. Cf. objections to the classification in C. Deeming, "The Lost and the New "Liberal World" of Welfare Capitalism: A Critical Assessment of Gøsta Esping-Andersen's The Three Worlds of Welfare Capitalism a Quarter Century Later' (2017) 16(3) Social Policy \& Society, pp. 405-22, at 409-10 (recalling Esping-Andersen's difficulties in classifying Australia).

117 H.A. Simon, Models of Man: Social and Rational: Mathematical Essays on Rational Human Behavior in a Social Setting (Wiley, 1957). See also human and financial markets myopia in Clark, n. 110 above.

118 J. Thomä \& H. Chenet, 'Transition Risks and Market Failure: A Theoretical Discourse on Why Financial Models and Economic Agents May Misprice Risk related to the Transition to a Low-Carbon Economy' (2017) 7(1) Journal of Sustainable Finance \& Investment, pp. 82-98, at 92; see also Shiller, n. 110 above, pp. 21-2.

119 Shiller, n. 110 above, p. 22. See also the conventional presumption that managerial decisions are informed and disinterested (i.e., the business judgment rule), which is becoming less tenable; see Weber \& Hösli, n. 10 above, p. 172.

120 Taleb, n. 2 above.

121 M.L. Weitzman, 'Fat-Tailed Uncertainty in the Economics of Catastrophic Climate Change' (2011) 5(2) Review of Environmental Economics and Policy, pp. 275-92, at 286.

122 Carney, n. 20 above. 
investment horizons that are considerably shorter than those that would accurately account for climate-related financial risk. ${ }^{123}$ Even long-term investors such as pension funds routinely follow short-term investment horizons (for example, three to five years) by relying on backwards-looking or short-termed ratios in credit and equity research analysis. ${ }^{124}$ Such short-sightedness will prove fatal for regulation meant to anticipate systemic risk and provide future generations of citizens with both pensions and a stable climate.

This short-sightedness seems entrenched in the regulatory assumptions encased within the TCFD Recommendations, in which regulation is assumed to be a 'light touch' aimed at 'creating the conditions' or 'developing the frameworks' for markets to carry out their efficiency promise. ${ }^{125}$ Importantly, this is the approach that McVeigh seems to counter. By asking the Australian Federal Court to rule not only on disclosure duties but also on due diligence obligations, I argue that Mark $\mathrm{McVeigh}$ articulated the need for a normative approach to pension fund disclosure duties and an extension of the field of climate-related risk disclosures to embrace climate-related risk due diligence. Such a take is promising and seems confirmed by the settlement between McVeigh and REST.

This section has revealed that the TCFD Recommendations can be constructively criticized. The short-sighted focus on disclosure is irreconcilable with findings on the general overconfidence in market efficiency, herding, the distribution of climate risk as black swans with 'fat tails', and the tragedy of time horizons. By requiring that a retail pension fund actively oversees fund managers and advisers in making investment decisions, ${ }^{126} \mathrm{I}$ argue that $\mathrm{McVeigh}$ challenges the hands-off attitude currently expressed by pension funds vis-à-vis investment executives, which steers pension funds towards administrative rather than investment issues. ${ }^{127}$ Moreover, by requiring that executives comply with the TCFD Recommendations not only when disclosing climate-related risk but also when managing it, ${ }^{128}$ McVeigh underscores the value of due diligence within and beyond the Recommendations. Such a move is compatible with the Recommendations' content,

123 B. Christophers, 'Environmental Beta or How Institutional Investors Think about Climate Change and Fossil Fuel Risk' (2019) 109(3) Annals of the American Association of Geographers, pp. 754-74; see also Carney, n. 20 above.

124 M. Naqvi et al., 'All Swans are Black in the Dark: How the Short-Term Focus of Financial Analysis Does Not Shed Light on Long Term Risks', $2^{\circ}$ Investing Initiative \& Generation Foundation, Feb. 2017, pp. 40, 45 and 48, available at: https://2 degrees-investing.org/resource/all-swans-are-black-in-the-dark. Long-term investors are not demanding long-term risk assessments: ibid., pp. 58 and 62; Clark, n. 110 above, p. 13. See the complication of return requirements for pension funds given the different stakes in the management: W.A. Grier, Credit Analysis of Financial Institutions, $2^{\text {nd }}$ edn (Euromoney Books, 2007), p. 327. Cf. how public pension funds can be 'frontier investors', countering short-termism: J. Singh Bachher, A.D. Dixon \& A.H.B. Monk, The New Frontier Investors: How Pension Funds, Sovereign Funds, and Endowments are Changing the Business of Investment Management and Long-Term Investing (Palgrave Macmillan, 2016), pp. viii and $30 \mathrm{ff.}$

125 See Christophers, n. 109 above, p. 1118.

${ }^{126}$ McVeigh, n. 1 above, p. 4.

127 Sy, n. 63 above.

${ }^{128}$ McVeigh, n. 1 above, p. 4. For an approach going beyond disclosures see B. Sjåfjell, 'Beyond Climate Risk: Integrating Sustainability into the Duties of the Corporate Board' (2018) 23 Deakin Law Review, pp. 41-61. 
lessons from behavioural law and economics, socio-legal studies on the role of organizational culture, and epistemological conventions that may obstruct climate risk appreciation and provoke misfires, as I show in the next section.

\section{MISFIRES: THE CULTURAL CASE FOR CLIMATE-RELATED FINANCIAL RISK}

\subsection{The Misfires of Climate Risk Disclosures}

The previous section elucidated that it is fallacious to rely on the TCFD Recommendations exclusively as a disclosure instrument. Instead, risk assessment via disclosure must be complemented by the risk management of climate-related financial risk via due diligence. This section centres on a regulatory approach which can effectively respond to the challenges posed by climate-related financial risk for pension funds. Findings from behavioural law and economics, the sociology of law and criminal sociology are consulted to shed light on the role of culture, notably organizational culture (and its attendant misfires), and to make the 'cultural case', rather than only the 'business case', for climate-related financial risk. Misfires refer to the disruption of risk calculations arising from omitted factors and can lead to dreadful consequences. ${ }^{129}$

McVeigh's demand for a normative reconceptualization of pension fund disclosures and due diligence illustrated that the business case for pension funds to align their investment portfolios with climate risk assessments is insufficient. It implies that the market does not yet value climate risk and, consequently, the value the market will bestow on climate risk in the future may be wholly insufficient, notwithstanding disclosure. Defining climate risk as a financial risk and distinguishing physical and transition risks, as the TCFD does, turn climate risk from an amorphous concept into assessable components. ${ }^{130}$ Such 'codification' arguably has made climate-related financial risk calculable, ${ }^{131}$ but calculation models may prove unsatisfactory.

Accepting the TCFD Recommendations as disclosure instruments - because they make climate risk calculable - neglects the subjectivity of calculation models: at times, such models have facilitated descriptions of reality that favour the economic interests of organizations. ${ }^{132}$ Short of supervision, organizations may be able to construct risk in a self-interested way and distribute the consequences of their misfires among non-market actors, marginalized consumers, and even the environment itself. ${ }^{133}$ This well-known dynamic consists of socializing risks and internalizing rewards, notably profit. ${ }^{134}$

129 D. Nyberg \& C. Wright, 'Performative and Political: Corporate Constructions of Climate Change Risk' (2016) 23(5) Organization, pp. 617-38, at 618.

130 See also ibid., p. 628, short of referring to the TCFD.

131 Ibid., p. 629.

132 Ibid., p. 633.

133 Ibid.

134 See also M. Mazzucato, 'The Entrepreneurial State: Socializing Both Risks and Rewards' (2018) 84 Real-World Economics Review, pp. 201-17. 
However, self-interested risk construction is not the only hurdle for the effective governance of climate-related financial risk in pension funds. Risk assessments may be misleading, biased, or oblivious. I remark on each of these shortcomings to show that business as usual through disclosure strategies is a regulatory problem as well as a business and financial challenge. This argument further supports the case for the TCFD Recommendations to become a normative expectation rather than a voluntary option and makes a 'cultural case', rather than only a 'business case', for climate risk.

Empirical research reveals that some approaches to risk have led to numerous 'misfires', mistaken calculations arising from unaccounted factors. For example, the evaluation of an investment project in terms of $\mathrm{CO}_{2}$ emissions alone led EnergyCo, a sizeable Australian energy company, to brand coal-seam gas production as cleaner than other fossil fuel-powered generation sources. ${ }^{135}$ Simultaneously, EnergyCo downplayed the project's emissions of methane, a potent GHG, and did not consider further values. For example, it failed to account for the local communities' perception of fracking as harmful from an environmental, health and aesthetic perspective in its climate risk evaluation. ${ }^{136}$ Such misfires reveal the massive challenges in pursuing a low-carbon society: while climate science has consolidated, political actors agonize over how to respond fully to its challenges. ${ }^{137}$ By leaning on corporate investee evaluations, pension funds may end up financing projects based on inaccurate risk calculations.

Awareness of 'conservatism bias' may lead pension funds to assess and revise climate-related risk in the right direction, but firms and people tend to respond insufficiently to new information. ${ }^{138}$ Entwined with conservatism bias, the 'endowment effect' may explain why pension funds prefer maintaining the status quo to selling off their carbon-intensive portfolios. Some carbon-intensive investments rank among the most profitable on the market, ${ }^{139}$ and pension funds may want to minimize the risk of profit loss that would result from selling them. ${ }^{140}$ Moreover, existing investment methods and tools, including fossil fuel investments, have a proven track record: past successes may prompt firms to use the same methods and tools, even though they may fail in the future. ${ }^{141}$

With regard to omissions, the 'business case' for climate-related financial risk may be insufficient in the aftermath of a misfire. Theoretically, entities should modify assessment models, and attempt to avoid further misfires by adopting better risk assessment and management procedures and accounting for uncertainties. ${ }^{142}$ Nevertheless,

\footnotetext{
135 Nyberg \& Wright, n. 129 above, p. 632.

136 Ibid.

137 Ibid., p. 621.

138 On the conservatism bias, see Shiller, n. 110 above, p. 20.

139 See the BHP and Rio Tinto Group participations, as explained in M. Burgess, 'Wildfires Are Forcing Aussie Pension Funds to be More Green', Bloomberg, 13 Feb. 2020, available at: https://www.bloomberg.com/news/articles/2020-02-13/wildfires-are-forcing-aussie-pension-funds-to-bemore-green.

${ }^{140}$ On regret avoidance as one of the explanations of the endowment effect see Korobkin, n. 26 above, p. 315 .

141 E. Schoenberger, The Cultural Crisis of the Firm (Blackwell, 1997).

142 On the distinction between risks and uncertainties see Section 2 above.
} 
misfires do not utterly dismantle an entity's construction of risk; the construction is not modified so much as adapted to the results. For instance, it has emerged that in the event of a disaster, potential dangers are not easily detectable within existing streams of information and decisions. Signals may seem mixed, weak, or routine in the context of individual decisions. ${ }^{143}$ Hence, signals are normalized under the influence of the history, culture, political environment and organization of the firm upon its members. ${ }^{144}$ In climate change matters such normalization may lead to 'carbon lock-ins', reinforcing and perpetuating carbon-intensive activities over time and possibly delaying technological transitions for decades. ${ }^{145}$ Pension funds can find themselves enmeshed in carbon lockins notwithstanding the TCFD Recommendations.

Misfires continue to happen. Thus, Australian regulators have issued voluntary guidance on disclosure, including climate risk disclosure ${ }^{146}$ but disclosure obligations have not been enforced. ${ }^{147}$ Further, it has emerged that regulators do not assess relevant information sufficiently. ${ }^{148}$ Generally, sustained engagement with climate change issues has not yet substantially changed corporate behaviour in Australia. ${ }^{149}$ If business and financial entities are to become part of the solution to climate change ${ }^{150}$ more research is needed on how to complement the approach to climate risk disclosures with a normative discourse based on binding regulation. Such a discourse would purposefully investigate how due diligence standards could assist entities to transition away from GHG-intensive business models and towards investment in clean energy and sustainability practices. ${ }^{151}$ I call this the 'cultural case' for climate-related financial risk, which is instrumental in measuring whether pension funds have fulfilled their fiduciary duties towards beneficiaries.

\subsection{The Case for Due Diligence in Financial Climate Risk}

This section discusses the need to complement disclosure with due diligence to foster regulation that is responsive to the challenges posed by climate-related financial risk

143 On both points see D. Vaughan, 'The Normalization of Deviance: Signals of Danger, Situated Action, and Risk', in H. Montgomery, R. Lipshitz \& B. Brehmer (eds), How Professionals Make Decisions (Lawrence Ehrlbaum Associates, 2005), pp. 255-76, at 258-9. At times, potential dangers are followed up and modified: ibid., pp. $258 \mathrm{ff}$.

144 Vaughan, ibid., pp. $259 \mathrm{ff}$, especially at 266.

145 The originator of research on carbon 'lock-ins' is G.C. Unruh, 'Escaping Carbon Lock-in' (2002) 30(4) Energy Policy, pp. 317-25 (who divides them into technological, organizational, industrial, societal, and institutional sources: ibid., p. 318). See also C. Holley, L. Phelan \& C. Shearing (eds), Criminology and Climate (Routledge, 2021).

146 Australian Accounting Standards Board \& Auditing and Assurance Standards Board, 'Climate-related and Other Emerging Risk Disclosures: Assessing Financial Statement Materiality Using AASB Practice Statement 2', Dec. 2018, available at: https://www.aasb.gov.au/admin/file/content102/c3/ AASB_AUASB_Joint_Bulletin_13122018_final.pdf.

147 Z. Caldwell, 'Corporations and Climate Change: An Investigation of Mandatory Climate Risk Disclosure in Australia' (2020) 37(1) Environmental \& Planning Law Journal, pp. 3-17.

148 J. Peel et al., 'Governing the Energy Transition: The Role of Corporate Law Tools' (2019) 36(5) Environmental \& Planning Law Journal, pp. 459-76.

149 B. McDonnell et al., 'Green Boardrooms?' (2021) 53(2) Connecticut Law Review, pp. 335-409.

150 See similarly Peel et al., n. 148 above (focusing on energy transition governance).

151 See the stress not only on disclosures, but also due diligence, in A. Foerster, 'Climate Justice and Corporations' (2019) 30(2) King's Law Journal, pp. 305-22, pp. 317-8. 
for pension funds. I revise the customary account of the TCFD instruments as a tool for disclosure and propose that courts can deploy them as a parameter of interpretation for due diligence. The case for due diligence is not intended to displace, but instead to complement disclosure on climate risk to ensure that the entity has control over risk assessment misfires. ${ }^{152}$

Notwithstanding ongoing discussions on the content of fiduciary duties, few would deny that pension funds act on behalf of their beneficiaries, subject to government regulation. This means that they act in the interests of beneficiaries and support their longterm welfare. ${ }^{153}$ The fiduciary obligation to promote private returns must take into account their public costs, ${ }^{154}$ especially when such costs risk misfiring and undercutting the very profits they generate, as in the case of carbon-intensive investments. In this respect the TCFD Supplemental Guidance for the Financial Sector, which is attached to the Recommendations, provides significant procedures to assist courts of law with targets and metrics of disclosure, as well as standards of due diligence, in assessing the fulfilment by pension funds of their fiduciary duties in terms of climate-related financial risk.

Courts that are asked to adjudicate climate change litigation and need to flesh out the requirements of the TCFD or related regulatory guidance may first evaluate whether a pension fund has established key climate-related targets (for example, on GHG emissions, water usage, or energy usage) in line with anticipated regulation, market constraints, or specific economic or financial objectives. ${ }^{155}$ With regard to metrics, a potent indicator of portfolio public costs is the portfolio carbon footprint, ${ }^{156}$ expressed by the TCFD as the 'weighted average carbon intensity metric', which admittedly is only a first step towards the complete calculation of portfolio carbon intensity. ${ }^{157}$

Unfortunately, the TCFD metrics presently exclude scope 3 emissions. ${ }^{158}$ Importantly, however, courts may deem the inclusion of scope 3 emissions as relevant in calculating the fund's exposure to climate-related financial risk concerning all carbon-intensive investments. ${ }^{159}$ The relevance of scope 3 emissions has already been

152 The Recommendations are allegedly ' $a$ foundation to improve investors' and others' ability to appropriately assess and price climate-related risk and opportunities' (emphasis added): TCFD Recommendations, n. 19 above, p. v. See the mechanisms that can support disclosures in Carney's view: stress testing and a price corridor (but not prudential rules), in Carney, n. 20 above, pp. 9 and 11.

153 Clark, n. 110 above, p. 13.

154 Richardson, n. 82 above, p. 626.

155 Objectives include efficiency; reaching financial targets; financial loss tolerances; net revenue goals for green products and services, or the avoidance of GHG emissions throughout the product life cycle: TCFD Annex, n. 101 above, p. 37; see ibid for further specifications on the determination and disclosure of targets.

156 Richardson, n. 82 above, p. 626.

157 TCFD Annex, n. 101 above, p. 37.

158 See Section 3 above.

159 Carbon-intensive investments are here defined as 'physical assets or companies with direct or indirect exposure to high levels of GHG emissions, such as those in the fossil fuel industry, or that are heavily reliant on fossil fuels', as in M. Fulton \& C. Weber, Carbon Asset Risk: Discussion Framework (World Resources Institute \& UNEP FI, 2012), p. 11. The GHG Protocol, indicated as the relevant method for emissions calculation by the TCFD, recommends that financial institutions account for investee 
recognized in Australian climate change litigation. ${ }^{160}$ Beyond carbon footprints, the judiciary may take into account additional metrics for climate-related risks - water, energy, land use, and waste management data, in particular - as well as climate-related opportunities (such as information on green products and services), where relevant and applicable. However, the TCFD Supplemental Guidance does not detail the content of the metrics it suggests. ${ }^{161}$

Beyond checking disclosure, the judiciary can rely on the TCFD to consider pension fund due diligence. While the TCFD Recommendations are generally undecided on the matter, the TCFD Supplemental Guidance for the Financial Sector offers guidelines for climate-related financial risk due diligence. ${ }^{162}$ Asset owners, including pension funds, are encouraged to identify their climate-related risks, as are other financial entities. Additionally, asset owners are advised to engage actively with investees to encourage better disclosure and risk practices at the investee level to ultimately improve data availability. ${ }^{163}$ Notably, the TCFD Supplemental Guidance recommends that financial organizations describe their risk management processes, which lie at the heart of due diligence systems.

In fact, the TCFD urges organizations to disclose procedures to 'mitigate, transfer, accept or control' climate-related financial risks and to prioritize the most material risks. In a further strand of TCFD Guidelines, asset owners, in particular, should evaluate their total portfolio position in terms of climate-related financial risks. Here, the TCFD is quite demanding: it recommends portfolio risk evaluations based on the transition to a lower-carbon energy supply, production, and use. ${ }^{164}$ Further, the TCFD Guidelines imply that targets and metrics are not only crucial for disclosure; asset owners should describe precisely how they use climate-related risk and opportunity metrics in each fund or investment strategy, how metrics have changed over time - where appropriate - and how they can be monitored. 165

One may wonder whether judicial reliance on TCFD documents is methodologically defensible. The TCFD Recommendations constitute transnational law which courts may consider, pending their adoption in binding form. Preliminarily, it would not be the first time that domestic courts have engaged with transnational law in climate change matters. ${ }^{166}$ In this context, transnational law becomes a

scope 3 emissions when the latter are significant compared with other sources of emissions or otherwise relevant: GHG Protocol, 'Technical Guidance for Calculating Scope 3 Emissions', 2013, p. 138.

160 See, e.g., Gloucester Resources Ltd v. Minister for Planning [2019] NSWLEC 7, paras $489 \mathrm{ff}$.

161 TCFD Recommendations, n. 19 above, p. 36. The TCFD specifies that financial entities should provide metrics for historical periods to allow for trend analysis and, where not apparent, describe the methodologies used to calculate or estimate climate-related metrics.

162 TCFD Annex, n. 101 above.

163 Ibid., p. 35.

164 Ibid., p. 36.

165 Ibid.

${ }^{166}$ L. Burgers, 'Should Judges Make Climate Change Law?' (2020) 9(1) Transnational Environmental Law, pp. 55-75. 
benchmark for interpretation used by domestic courts when applying domestic legal sources. $^{167}$

In any case, applying the TCFD as a benchmark for the interpretation of domestic law is relatively straightforward: it does not require a monist legal system, in which international law is automatically imported into national law short of a transforming instrument. In fact, applying the TCFD as a benchmark for the interpretation of domestic law equates to holding that domestic law is applied consistently with transnational law. Consistent interpretation has been found to eclipse the distinction between monist and dualist legal systems, ${ }^{168}$ rendering the approach to international law in the forum state non-dispositive of whether the court will apply supranational or transnational law. ${ }^{169}$ Nevertheless, certain requirements may exist for treating transnational or international law as a benchmark for interpretation. In Australia, for instance, domestic provisions must be able to accommodate a supranational law-compliant interpretation in so far as the statutory language permits. ${ }^{170}$ Notwithstanding such limitations, applying domestic law consistently with transnational law or international law is the most common way for domestic courts to engage with supranational law ${ }^{171}$ in common law and civil law traditions. ${ }^{172}$

We can derive three important takeaways from this exploration of the TCFD instruments as a benchmark for the interpretation of due diligence. Firstly, the business case for climate-related financial risk can be helpfully complemented by a 'cultural case', which recognizes and accounts for market-based, behavioural, and organizational inefficiencies. Secondly, the work of the TCFD is only partly disclosure based. It also offers a valuable opportunity for courts to spell out the role of pension fund due diligence in managing climate-related financial risk. Thirdly, McVeigh's reference to the TCFD not only for disclosure strategies but also for the vindication of due diligence duties by officers and directors in pension funds seems to mirror the extended reading of the TCFD instruments by the APRA. As recently as February 2020, the APRA encouraged the adoption of voluntary frameworks to assist entities not only with assessing and disclosing climate financial risk but also with risk management in line with the TCFD. ${ }^{173}$

167 On international law as a benchmark for interpretation in climate change litigation see E. Colombo, '(Un)Comfortably Numb: The Role of National Courts for Access to Justice in Climate Change Matters', in J. Jendrośka \& M. Bar (eds), Procedural Environmental Rights: Principle X in Theory and Practice (Intersentia, 2017), pp. 437-64.

168 A. Tzanakopoulos, 'Domestic Courts as the "Natural Judge" of International Law: A Change in Physiognomy', in J. Crawford \& S. Nouwen (eds), Select Proceedings of the European Society of International Law, Vol. 3 (Hart, 2011), pp. 155-68, at 161-5.

169 A. Nollkaemper, National Courts and the International Rule of Law (Oxford University Press, 2011), pp. 143-4 (referring to international law).

170 Ibid., p. 162.

171 Ibid., p. 117.

172 Ibid., p. 148.

173 APRA, 'Understanding and Managing the Financial Risks of Climate Change', 24 Feb. 2020, available at: https://www.apra.gov.au/understanding-and-managing-financial-risks-of-climate-change. See also ASX Corporate Governance Council, 'Corporate Governance Principles and Recommendations', $4^{\text {th }}$ edn, Feb. 2019, Recommendation 7.4, p. 28 (referring to disclosures only), available at: https://www.asx. com.au/documents/regulation/cgc-principles-and-recommendations-fourth-edn.pdf. 
Overall, the discussion underscores that McVeigh invites a broader conceptualization of the TCFD instruments. Pursuant to this broader conceptualization, the risk of misfires in assessing financial climate risk can be at least partially assuaged by diligent management. Within this broader conceptualization the work of the TCFD is a first step towards bridging the gap between voluntary and normative approaches to pension fund climate-related financial risk. It does so by offering standards and metrics that domestic courts can apply as a benchmark for interpretation when adjudicating cases on climate-related financial risk in pension funds, thus making the TCFD instruments a tool for comprehending and governing climate risk, rather than fostering uncoordinated voluntary practices.

\section{CONCLUSION}

Writing in 2013, John Braithwaite maintained that regulatory powers had not grown in proportion to the sophistication of financial markets. ${ }^{174}$ Such a statement is still accurate. To date, pension funds have shown that they cannot adequately manage climate-related financial risks and opportunities with regulatory instruments that make disclosure voluntary, as the TCFD purportedly does. A normative approach could meaningfully lead pension funds to account for their climate-related risks and opportunities. For its part, legal research confirms that '[r] egulatory detail matters', and clarifies that we can normatively redefine pension funds in ways that ensure financial and social stability if we so desire. ${ }^{175}$

Underscoring that global financial markets cannot be surrogate regulators, this article inquired into (i) the role of climate change litigation in promoting climate regulation by pension funds, and (ii) the relative importance of the risk management of climate-related financial risk (via due diligence) compared with risk assessment (via disclosure) in pension funds. As a landmark in the litigation over climate risk, a recently settled Australian case against pension funds, McVeigh, has helped to answer these questions.

Overall, the discussion has revealed that (i) the role of climate change litigation in promoting climate regulation by pension funds is one of 'expository justice', and demonstrates the adaptability of the law to the challenges posed by climate change; further, (ii) risk assessment via disclosure must be complemented by the management of climate-related financial risk (via due diligence). The TCFD instruments themselves, extolled as instruments of disclosure, can serve as a parameter for the interpretation of due diligence in pension fund climate risk. Only a forward-looking and preventative, rather than punitive, justice system can break the tragedy of the horizons caused by climate change and address outstanding distributive issues, notably the intergenerational justice associated with present-day pension fund investments.

The need for a 'regulatory infrastructure"176 through judicial or legislative determinations does not necessarily imply the expansion of public enforcement. Public enforcement itself can, in fact, be captured by finance capitalism and fail in its regulatory

\footnotetext{
${ }^{174}$ J. Braithwaite, 'Conclusion: Cultures of Redemptive Finance', in J. O’Brien \& G. Gilligan (eds), Integrity, Risk and Accountability in Capital Markets: Regulating Culture (Hart, 2013), pp. 269-87, at 275-6.

175 B. Black, 'Agents Watching Agents: The Promise of Institutional Investor Voice' (1992) 39 UCLA Law Review, pp. 811-93, at 815.

${ }^{176}$ For this expression, see Braithwaite, n. 174 above, p. 275.
} 
aims. ${ }^{177}$ A responsive regulatory infrastructure would allow for the incremental implementation of the TCFD Guidelines concerning both disclosure and due diligence. Such an implementation, flexible enough to meaningfully capture an organization's dynamics, would be reviewed by beneficiaries through active information gathering and engagement in their pension funds, as the plaintiff McVeigh showed before taking his pension fund to court. Whenever spaces for dialogue between pension funds and beneficiaries run aground, it will ultimately be for the courts or regulatory authorities to authenticate pension fund assessments and their management of climate-related financial risk. ${ }^{178}$

The rationale for such public enforcement intervention acquires greater heft when considering the duties of pension funds towards their beneficiaries and the systemic risk they can generate for financial and social stability. The process is far from certain. In fact, the study and practice of climate-related financial risk came under the spotlight in relation to the TCFD Recommendations only fully in 2017. Moreover, the incremental construction of a responsive regulatory infrastructure is expected to be intrinsically complex and evidence-intensive as a result of the sophistication and ever-changing nature of financial rocket science. ${ }^{179}$ Nevertheless, the complexity of present and future litigation against pension funds should not discourage legal scholars and practitioners. Courts have increasingly engaged with evidence-based judicial rulings and can generally rely on expert opinion to charter the adapted role of law in the new field of climate risk. ${ }^{180}$

McVeigh, the first case on disclosure and due diligence brought by a beneficiary against his public pension fund, appears to test the waters for a more responsive regulatory infrastructure in climate risk matters. The case can ultimately spark the longneeded dialogue between pension funds and beneficiaries, thus opening 'spaces for ethical deliberation' on why and how we must regulate pension fund climate risk. ${ }^{181}$

\footnotetext{
177 Ibid.

178 This may also be one of the ways to flesh out what Braithwaite calls 'radical privatization' of enforcement to check on public enforcement: ibid.

179 Ibid., pp. 275-6.

180 On the evidence-based judicial process see A. Alemanno, 'The Emergence of the Evidence-based Judicial Reflex: A Response to Bar-Siman-Tov's Semiprocedural Review' (2013) 1(2) The Theory and Practice of Legislation, pp. 327-40.

181 On 'spaces for ethical deliberation' see Braithwaite, n. 174 above, p. 278.
} 